\title{
The Application of Information Gap Activity to Improve Speaking Skill of Nursing Students
}

\author{
Abdul Aziz Rifaat ${ }^{1}$, Nyayu Yayu Suryani ${ }^{2}$ \\ email: azizlie2@gmail.com \\ ${ }^{1}$ STIK Siti Khadijah, Palembang \\ ${ }^{2}$ STIK Siti Khadijah, Palembang
}

Received: 03 May 2020 Accepted: 16 May 2020

DOI: $10.24256 /$ ideas.v8i1.1322

\begin{abstract}
Nowadays, Speaking as one of four skills taught in English become popular and very important to be learned. Since 4.0 revolution era has been launched, the students from junior high school to university level are interested to study English especially speaking skill. The study aimed to investigate the significant difference in speaking achievement before and after the students were taught using Information Gap Activity. The pre-experimental design through one group pretest-posttest design was used in this study. The $4^{\text {th }}$ semester students of S1 Nursing Science program at STIK Siti Khadijah Palembang in academic year $2019 / 2020$ was the population of this study. The sample of this study was all of the population of this study. Since the total number of the population was 22 students, they all selected as the sample in this study. The test was administered twice as pretest and posttest. The result of the test was analyzed by using t-test through SPSS (Statistical Package for Social Science).
\end{abstract}

Keywords: speaking; information gap activity

\section{Introduction}

Speaking is one of communication tool. As a tool of communication, it should be supported by some understandable sentences and words so that the listener could understand those sentences and words. The complex process of interaction between two people or more so that they could understand each other means speaking (Brown, 1994; Masruddin, 2018). When the people speak, they produce some sentences or utterances that would be listened and analyzed by the listener so that they could respond as the first speaker expected.

As a productive skill from four skills in English, speaking is very important to be learned by the English learners. Clark and Clark (1997) state that speaking is basic tool for communication. As a basic tool for communication, speaking plays an important role in the process of learning English. Speaking skill requires the learners to be active to practice their skill. The learners could not master this skill if the students tend to be passive students in learning this skill. The more active the learners perform in this skill the more value the learners get from this 
skill.

Speaking is the way of communication. Two people are exchanging information or having a communication or conversation needs (Doff, 1987). The process of exchanging information in the communication is the speaking existence itself. Speaking process would be meaningful if the process of exchanging information is has been done. Speaking needs the listener and responds from the listener itself. Nunan (1999) adds that speaking is an interactive process of constructing meaning that involves producing, receiving, and processing information received orally.

The definition of speaking was stated by Wilson (1983) as development of the relationship between speaker and listener. The communication between two people or more is interpreted as speaking. Someone could not do a communication if he/she does not do a communication to the listener. In the other hand, the listener should give respond to the speaker so that the communication is exist.

English at STIK Siti Khadijah is taught as special subject especially at Nursing Science program. Moreover, speaking is the priority skill among the four skills to be focused. Speaking seems to be more important skill to be mastered by the students among the other three skills because the nursing students in the future will face some possibilities asking them to communicate in English. Moreover, as Mr. President says, Indonesian people must be digitally literacy to face 4.0-revolution era.

The major problem then comes to STIK Siti Khadijah. Since the students come from many different educational backgrounds and areas, they bring many different problems. Some students avoid speaking practice because they afraid of having misspelling and mistakes. In the other hand, the students who come from particular area involve their speaking accent when speaking practice. Other problems such as the use of inappropriate vocabularies, incorrect structures, and mispronunciation were becoming the common problems when the students practice speaking.

Information gap activity, as one of the techniques in teaching English should be the alternative for the students to be applied in order to improve their English result. Information gap activity indirectly guide the students to build the communication with others. As Raptou (2002) states that in information gap activities, one person has certain information that must be shared with others in order to solve the problem, gather information, or make decisions.

Harmer (1991) describes Information gap as an "empty space" of conversation process that should be filled by the speakers in order to build similar character, view, or information which is spoken. The information gap activity functions as a media to fill the information between the two speakers or more so that the information could be actually informed and produced the accurately between the speakers.

In line to Harmer's description, Kayi (2007) adds that the information gap activities are students' reaction in joining the conversational activity in pair or group of learning. The first student acts as the informer for other students. The communication between them let them interact each other to find information clearly. 
Moreover, Neu dan Resser (1997) describes that information gap activity as a condition where a person that want to share a certain information in solving a problem and gathering it or making decision of it. In other words, this technique indirectly force the speaker to be active to communicate between two or more speakers.

Basturkmen (1994) cited in Almira, Aziz, Erdina (2017) asserts that Information Gap Activity is for fascinating the position in the completing the task and to promote the authentic of target language for the students. This activity is appropriate for the students when they work in pair or group. Using this activity indirectly stimulate the students to be active in speaking.

The previous study that was done by Almira, Aziz, and Erdina (2017) entitled Information Gap in Teaching Speaking was strongly related to this study. In their study Almira and friends stated that their study aimed to find out whether or not the use of information gap technique can improve students' performance in English speaking ability and helps teachers in teaching speaking. The result of their study describes that the posttest result was higher that the pretest result. The conclusion of the study was that information gap can be used as one of alternative techniques in teaching speaking.

For this reason the writer then interested in offering an activity in learning speaking. Such technique is information gap activity. This activity hopefully could stimulate the English learners especially the $4^{\text {th }}$ semester students at nursing science study program STIK Siti Khadijah Palembang in academic year 2019/2020.

Based on the explanation above, the writer formulated the questions for this study; is there any significant difference before and after the students were taught using Information Gap Activity? The objective of this study is to find out the significant difference in speaking achievement before and after the students were taught using information gap activity.

\section{Method \\ Method of the Study}

The pre-experimental method was used in this study using one group pretest-posttest design. It means that the experimental group only will be treated because there will be no control group in this study. The design of one group pretest-posttest is as follow (Creswell, 2008)

\section{$01 \times 02$}

\section{Figure 1. One Group Pretest-Posttest Design}

The study was done at STIK Siti Khadijah Palembang. The population of this study was be the $4^{\text {th }}$ semester students of S1 Nursing Science program at STIK Siti Khadijah Palembang in academic year 2019/2020. The total sampling was used to select the sample. The total number of the sample is 22 students.

\section{Technique for Collecting and Analyzing the Data}

The test was used in this study as an instrument to collect the data. The test was administered twice as pretest and posttest. The pretest was given before the treatment and the posttest was given after the treatment. There were three phases in collecting the data. The first phase is giving the result to each students, finding the mean, and comparing the means of the tests. The result was given 
based on the interval: 9-10 (Very Good), 7-8 (Good), 4-6 (Fair), and 1-3 (Poor).

The SPSS program was used to analyzed the result of the tests. The mean of the pretest and posttest was compared to find out the significant difference before and after the treatment given to the $4^{\text {th }}$ semester students of S1 nursing science study program at STIK Siti Khadijah Palembang.

\section{Results}

The study was implemented to the $4^{\text {th }}$ semester students of S1 Nursing Science program at STIK Siti Khadijah Palembang in academic year 2019/2020. The study was implemented in March 2020 intensively. The pretest was given before the treatment and the posttest was given after the treatment in this study. The result of the test was presented in form of table 1 and table 2

Table 1. The Score of Pre-test 
IDEAS, Vol. 8, No. 1, June 2020

\begin{tabular}{|c|c|c|c|c|c|c|c|c|}
\hline \multirow[t]{2}{*}{ No } & \multirow[t]{2}{*}{ SI } & \multicolumn{7}{|c|}{ Aspect scored } \\
\hline & & $\mathbf{v}$ & G & $\mathbf{F}$ & IC & $\mathbf{P}$ & TS & CT \\
\hline 1 & $\mathrm{~A}$ & 1 & 1 & 1 & 1 & 1 & 5 & $\mathrm{~F}$ \\
\hline 2 & $\mathrm{~B}$ & 1 & 1 & 1 & 1 & 1 & 5 & $\mathrm{~F}$ \\
\hline 3 & $\mathrm{C}$ & 1 & 1 & 0 & 0 & 1 & 3 & $\mathrm{P}$ \\
\hline 4 & $\mathrm{D}$ & 2 & 1 & 1 & 1 & 1 & 6 & $\mathrm{~F}$ \\
\hline 5 & $\mathrm{E}$ & 1 & 1 & 1 & 0 & 1 & 4 & $\mathrm{~F}$ \\
\hline 6 & $\mathrm{~F}$ & 1 & 1 & 1 & 1 & 1 & 5 & $\mathrm{~F}$ \\
\hline 7 & $\mathrm{G}$ & 1 & 1 & 1 & 0 & 1 & 4 & $\mathrm{~F}$ \\
\hline 8 & $\mathrm{H}$ & 1 & 1 & 1 & 0 & 0 & 3 & $\mathrm{P}$ \\
\hline 9 & I & 1 & 1 & 1 & 1 & 1 & 5 & $\mathrm{~F}$ \\
\hline 10 & $\mathrm{~J}$ & 2 & 1 & 2 & 1 & 1 & 7 & G \\
\hline 11 & $\mathrm{~K}$ & 1 & 0 & 1 & 1 & 1 & 4 & $\mathrm{~F}$ \\
\hline 12 & $\mathrm{~L}$ & 1 & 1 & 1 & 1 & 1 & 5 & $\mathrm{~F}$ \\
\hline 13 & $\mathrm{M}$ & 1 & 1 & 1 & 2 & 1 & 6 & $\mathrm{~F}$ \\
\hline 14 & $\mathrm{~N}$ & 1 & 1 & 0 & 1 & 0 & 3 & $\mathrm{P}$ \\
\hline 15 & 0 & 1 & 1 & 1 & 0 & 0 & 3 & $\mathrm{P}$ \\
\hline 16 & $\mathrm{P}$ & 1 & 1 & 1 & 0 & 1 & 4 & $\mathrm{~F}$ \\
\hline 17 & $\mathrm{Q}$ & 1 & 1 & 1 & 2 & 2 & 7 & $\mathrm{G}$ \\
\hline 18 & $\mathrm{R}$ & 1 & 1 & 1 & 1 & 1 & 5 & $\mathrm{~F}$ \\
\hline 19 & $\mathrm{~S}$ & 1 & 1 & 2 & 2 & 1 & 7 & $\mathrm{G}$ \\
\hline 20 & $\mathrm{~T}$ & 1 & 1 & 1 & 1 & 1 & 5 & $\mathrm{~F}$ \\
\hline 21 & $\mathrm{U}$ & 1 & 1 & 1 & 1 & 1 & 5 & $\mathrm{~F}$ \\
\hline 22 & $\mathrm{~V}$ & 1 & 1 & 1 & 2 & 1 & 6 & $\mathrm{~F}$ \\
\hline
\end{tabular}

Table 2. The Score Post-test

\begin{tabular}{lllllllll}
\hline No & SI & \multicolumn{9}{c}{ Aspect scored } & & & \\
\cline { 3 - 9 } & & V & G & F & IC & P & TS & CT \\
$\mathbf{1}$ & A & 2 & 1 & 1 & 2 & 1 & 7 & G \\
$\mathbf{2}$ & B & 1 & 1 & 1 & 2 & 1 & 6 & F \\
$\mathbf{3}$ & C & 1 & 1 & 0 & 0 & 1 & 5 & F \\
$\mathbf{4}$ & D & 2 & 1 & 1 & 2 & 1 & 7 & G \\
$\mathbf{5}$ & E & 1 & 1 & 1 & 0 & 1 & 5 & F \\
$\mathbf{6}$ & F & 1 & 1 & 2 & 2 & 1 & 7 & G \\
$\mathbf{7}$ & G & 1 & 1 & 1 & 0 & 1 & 5 & F \\
$\mathbf{8}$ & H & 1 & 1 & 1 & 0 & 0 & 5 & F \\
$\mathbf{9}$ & I & 1 & 1 & 1 & 1 & 1 & 5 & F \\
\hline
\end{tabular}




\begin{tabular}{lllllllll}
\hline $\mathbf{1 0}$ & $\mathrm{J}$ & 2 & 1 & 2 & 2 & 1 & 8 & $\mathrm{G}$ \\
$\mathbf{1 1}$ & $\mathrm{K}$ & 1 & 0 & 1 & 1 & 1 & 4 & $\mathrm{~F}$ \\
$\mathbf{1 2}$ & $\mathrm{L}$ & 2 & 1 & 1 & 1 & 1 & 7 & $\mathrm{~F}$ \\
$\mathbf{1 3}$ & $\mathrm{M}$ & 1 & 1 & 1 & 2 & 1 & 7 & $\mathrm{G}$ \\
$\mathbf{1 4}$ & $\mathrm{N}$ & 1 & 1 & 0 & 1 & 0 & 3 & $\mathrm{P}$ \\
$\mathbf{1 5}$ & $\mathrm{O}$ & 1 & 1 & 1 & 2 & 1 & 6 & $\mathrm{~F}$ \\
$\mathbf{1 6}$ & $\mathrm{P}$ & 2 & 1 & 2 & 2 & 1 & 8 & $\mathrm{G}$ \\
$\mathbf{1 7}$ & $\mathrm{Q}$ & 2 & 2 & 2 & 2 & 1 & 9 & $\mathrm{VG}$ \\
$\mathbf{1 8}$ & $\mathrm{R}$ & 1 & 1 & 1 & 2 & 1 & 6 & $\mathrm{~F}$ \\
$\mathbf{1 9}$ & $\mathrm{S}$ & 2 & 1 & 1 & 2 & 1 & 7 & $\mathrm{G}$ \\
$\mathbf{2 0}$ & $\mathrm{T}$ & 1 & 1 & 1 & 1 & 1 & 5 & $\mathrm{~F}$ \\
$\mathbf{2 1}$ & $\mathrm{U}$ & 2 & 1 & 1 & 1 & 1 & 6 & $\mathrm{~F}$ \\
$\mathbf{2 2}$ & $\mathrm{V}$ & 1 & 1 & 1 & 2 & 1 & 6 & $\mathrm{~F}$ \\
\hline
\end{tabular}

\section{Notes:}

SI : students' initial

$\mathrm{V}$ : vocabulary

G : grammar

F : fluency

IC : interactive communication

$\mathrm{P} \quad$ : Pronunciation

TS : total score

CT : category

The students' score then categorized as below:

Table 3. Students' Range Score and Category

\begin{tabular}{cc}
\hline Score Range & Category \\
\hline $9-10$ & Excellent \\
$7-8$ & Good \\
$4-6$ & Fair \\
$1-3$ & Poor \\
\hline
\end{tabular}

The table 1 and the table 2 show two difference scores and categories. The table 1 shows the pre-test score and the table 2 shows the post-test score. At the pretest, the lowest score was 3 and the highest score was 7. The mean score was 4.86 and standard deviation was 1.283. At the posttest, the lowest score was 4 and the highest score was 9. The mean score was 6.05 with standard deviation was 1.397. The students category was in line to the students score. It can be seen from the figures below: 


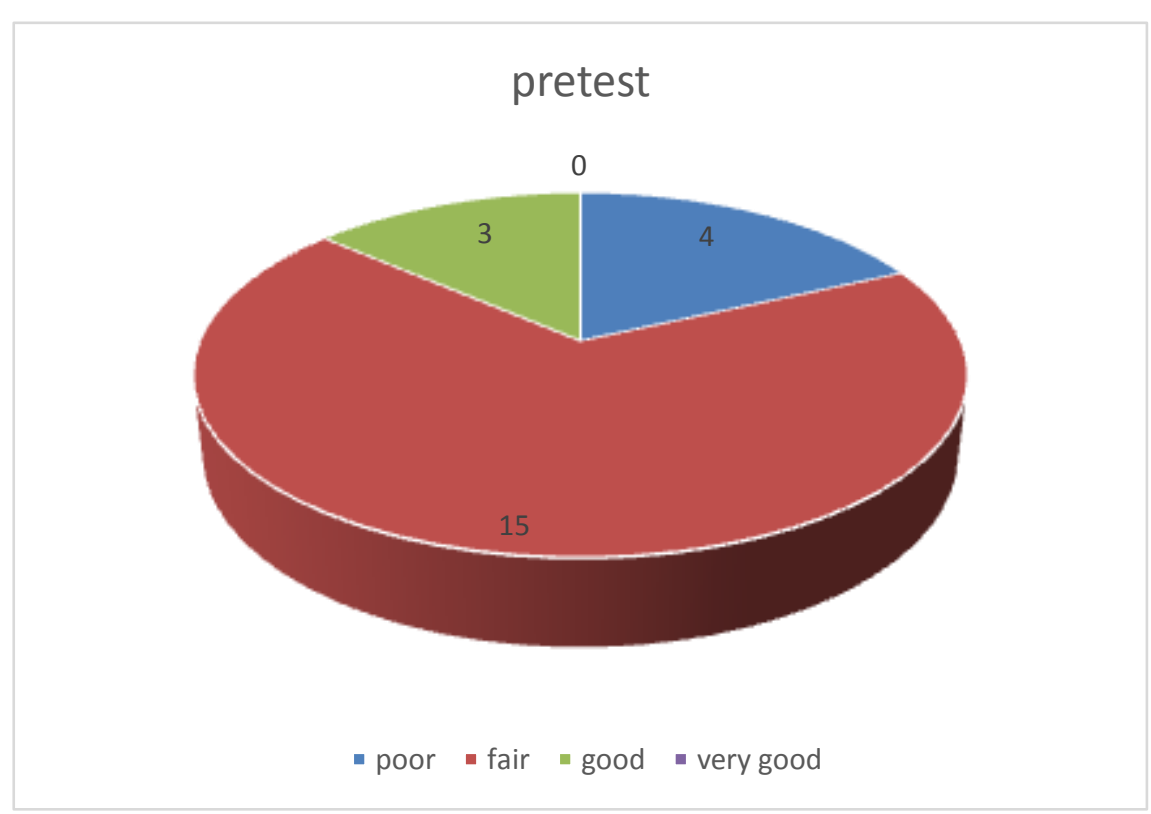

Figure 2. Students' Pretest Category

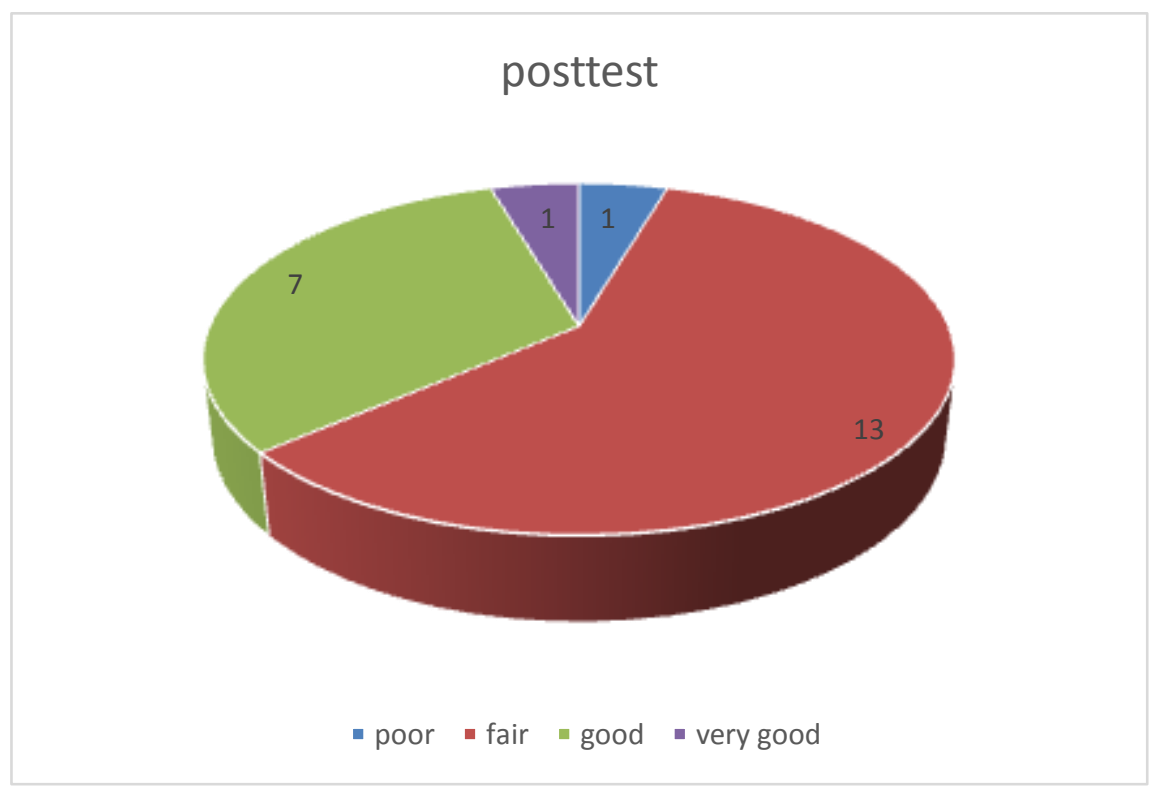

Figure 3. Students' Posttest Category

From 22 students in the pretest, it was found that there were 4 students at the poor category, 15 students at fair category, 3 students at good category, and no student at very good category. After posttest was given, there were 1 student at poor category, 13 students at fair category, 7 students at good category, and 1 student at very good category.

Since the correlation between pre-test and post-test in the experimental group was 0.694 and the significant level was 0.00 . The value of sig ( 2 tailed) was 0.00 . Since 0.00 was lower than alpha value 0.05 , it can be interpreted that the Information Gap Activity which was given was effective. The paired sample t-test 
was used to analyzed the result of the pretest and posttest. The SPSS program was applied during the process of analyzing those results.

\section{Discussion}

The aim of this study was to find out the significant difference in speaking achievement before and after the students were taught using Information Gap Activity. The problems the writer found from the students such as lack of vocabulary, inappropriate structure, feel shy, or mispronunciation were can be solved by the students after passing the treatment. For example, in the pretest the some of the students feel shy, do not interactive, mispronounce in speaking. After passing some treatment, the students look interactive, produce some new vocabularies, pronounce correctly and feel confident. It means that the Information Gap activity influences them and plays the role as a trigger to improve the students speaking skill.

Using Information Gap Activity indirectly forces the students to be active in speaking. Since the students need to exchange the information to fill in the gap, both of them have to build the communication bridge so that each of them understand each other. Once the gap appears, the students who involve in the communication needs to reconstruct it again.

\section{Conclusion}

The writer concluded that Information Gap Activity could improve students achievement in speaking skill significantly. The data could be seen from the students mean score in the pretest and posttest. The students score in the posttest better than the students score in the pretest. In addition, applying this activity to the $4^{\text {th }}$ semester nursing science students at STIK Siti Khadijah positively influence the students. The students looks more communicative in speaking class. Actually, there were some factors cause this improvement. The condition in the classroom and campus could be internal factors that influenced them. The total number of the students in the classroom is 22 students. The students could interactively communicate in the classroom. Moreover, the campus condition was still not very active. This situation can be exploited by the students to pass the treatment effectively.

\section{References}

Almira, R V. Aziz, Z. \& Erdina, N (2017). Information Gap in Teaching Speaking. Research in English and Education, 2 (2), June 2017.

Amaro, G Speaking Rubric. Id.scribd.com. Accessed on March 21 2020.

Brown, H. Douglas. (1994). Principles of Language Learning and Teaching, London, Longman. 
Clark, H. H and Eve, V. C. (1997). The Foreign Language Learner: A Guide for Learner. New York: Regent Publishing Company, Inc.

Creswell, J. W. (2010). Educational Research: Planning, Conducting, and Evaluating Quantitative and Qualitative Research. Upper Saddle River, NJ: Pearson Education Inc.

Doff, A. (1987). Teaching English. Cambridge: University Press.

Harmer, J. (1991). How to Teach English. Edinburgh Gate: Pearson Education Limited.

Kayi. H. (2006). Teaching Speaking; Activities to Promote Speaking in Second Language. Internet TESL Journal. Vol XII No 11. November 2016.

Septiyana, L. (2019). Designing English Speaking Materials Using Task- Based Language Teaching (TBLT) for Islamic Economics Students. IDEAS: Journal on English Language Teaching and Learning, Linguistics and Literature, 7(2). doi:https://doi.org/10.24256/ideas.v7i2.1031

Masruddin, M. (2018). The Efficacy of Using Short Video through Group Work in Teaching Speaking to Indonesian English as Foreign Language (EFL) Students. Arab World English Journal, 9 (3), 282-293. DOI: https://dx.doi.org/10.24093/awej/vol9no3.19

Masruddin, M. (2018). The Students Interest towards the Use of Natural Approach in Teaching Speaking. IDEAS: Journal on English Language Teaching and Learning, Linguistics and Literature, 1(2). doi:https://doi.org/10.24256/ideas.v1i2.169

Neu, H and Reeser, T. W. (1997). Information Gap Activities for Beginning French Classes. Boston; Heinle \& Heinle.

Nunan, D. (1999). Second Language Teaching and Learning. Boston:

Heinle and Heinle.

Raptou, V. (2002). Using Information Gap Activities in the Second Language Classroom. http;/www.caslt.org. Accessed on February 2020.

Wilson, S.(1983). Living English Structure. London: Longman. 